ISSN: 2224-0616

Int. J . Agril. Res. Innov. \& Tech. 4 (1): 32-35 , June, 2014

Available online at http:// www.ijarit.webs.com

\title{
GENETIC DIVERSITY OF SOME CHILI (Capsicum annuUm L.) GENOTYPES
}

\author{
M.J. Hasan', M.U. Kulsum², M.Z. Ullah ${ }^{3}$, M. Manzur Hossain ${ }^{4}$ and M. Eleyash Mahmud ${ }^{5}$ \\ Received 22 December 2013, Revised 25 May 2014, Accepted 28 June 2014, Published online 30 June 2014
}

\begin{abstract}
A study on genetic diversity was conducted with 54 Chili (Capsicum annuum L.) genotypes through Mohalanobis's $\mathrm{D}^{2}$ and principal component analysis for twelve quantitative characters viz. plant height, number of secondary branch/plant, canopy breadth , days to first flowering, days to $50 \%$ flowering, fruits/ plant, 5 fruits weight, fruit length, fruit diameter, seeds/fruit, 1000 seed weight and yield/plant were taken into consideration. Cluster analysis was used for grouping of 54 chili genotypes and the genotypes were fallen into seven clusters. Cluster II had maximum (13) and cluster III had the minimum number (1) of genotypes. The highest inter-cluster distance was observed between cluster I and III and the lowest between cluster II and VII. The characters yield/plant, canopy breadth, secondary branches/plant, plant height and seeds/fruit contributed most for divergence in the studied genotypes. Considering group distance, mean performance and variability the inter genotypic crosses between cluster I and cluster III, cluster III and cluster VI, cluster II and cluster III and cluster III and cluster VII may be suggested to use for future hybridization program.
\end{abstract}

Keywords: Chili, Capsicum annuum, Cluster and Genetic diversity

\footnotetext{
${ }^{1}$ Principal Scientific Officer, Hybrid Rice Division, Bangladesh Rice Research Institute, Joydebpur, Gazipur, Bangladesh

${ }^{2}$ Scientific Officer, Hybrid Rice Division, Bangladesh Rice Research Institute, Joydebpur, Gazipur, Bangladesh

${ }^{3}$ Field Coordinator (Vegetable), AVRDC, Bangladesh

${ }^{4}$ Assistant Information Officer (Crop Production), Agriculture Information Services, Khamarbari, Farmgate, Dhaka-1215

${ }^{5} \mathrm{PhD}$ fellow BSMRAU and Plant Breeder, Energypac Agro Ltd. Monipur, Gazipur, Bangladesh

*Corresponding author's email: jamilbrri@yahoo.com (M.J. Hasan)
}

\section{Introduction}

Chili (Capsicum annuum L.) is grown worldwide both as a spice and as a vegetable crop and world's second most important solanaceous vegetable after tomato. Chili is an important commercial crop of Bangladesh and grown for its green fruits as vegetable and in ripe dried fruits as spice and throughout the world because of its pungency and pleasant flavors. However, consumption in small amount enriches our diet as and considered good sources of minerals, vitamins and other food components. Almost all the varieties of low and medium pungency cultivated on a field scale in Bangladesh are belonged to Capsicum annuum. A number of cultivars are grown in Bangladesh differing in habit, yield and consumer's preference and in size, shape, color and pungency of the fruit. Chili is grown practically all over Bangladesh in Rabi and Kharif season and area under cultivation is 259383 acres. Most of the varieties cultivated in Rabi season and production is about 176134 metric ton but the yield is only 1.68 metric ton per hectare (BBS, 2011). The lack of improved genotypes is the main constraint to low yield. Assessment of different desirable traits spread over diverse genotypes is important to rapid advance in yield improvement of any crop. The importance of genetic diversity in the improvement of a crop has been studied in both self and cross-pollinated crop (Gaur et al., 1978). The plant breeders are always interested to know the genetic divergence among the varieties available due to reasons that crosses between genetically diverse parents are likely to produce high heterotic effect (Ramanujam et al., 1974) and crosses involving distantly related parents within the same species produce wide spectrum of variability. A logical way to start any breeding program is to collect precise information on the nature and degree of genetic divergence that would help the plant breeder in choosing the right type of parents for purposeful hybridization in heterosis breeding (Patel et al., 1989). Moreover, evaluation of genetic diversity is important to know the source of genes for a particular trait within the available germplasm (Tomooka, 1991). Genetic divergence is a basic requirement for effective selection within the existing population or population arising out of hybridization. More diverse the parents within a reasonable range, better are the chances of improving economic characters under 
consideration in the offspring. Mohalanobis's $\mathrm{D}^{2}$ statistic of multivariate analysis is recognized as a powerful tool in quantifying the degree of genetic divergence among the populations. Therefore, the present study was undertaken to assess the genetic diversity in 54 genotypes of chili and to identify suitable donors for a successful breeding program in this crop. Farhad et al. (2010) and Dutonde et al. (2008) have also been conducted similar studies in chili.

\section{Materials and Methods}

The experiment was conducted at Research and Development Farm of Energypac Agro Ltd., during Rabi season of 2011-12. The experimental farm is located at Monipur, about $20 \mathrm{~km}$ away from Gazipur chowrasta having $24.00^{\circ} \mathrm{N}$ latitude and $90.25^{\circ} \mathrm{E}$ longitude with an elevation of 8.4 meter from the sea level. A total 54 genotypes of chili (Capsicum annuum L.), collected from Bangabandhu Sheikh Mujibur Rahman Agricultural University (BSMRAU), local and exotic sources were included in this study. The experiment was laid out in Randomized Block Design with three replications having plot size of $4.0 \mathrm{sq} \mathrm{m}$ providing a spacing of $60 \times 40 \mathrm{~cm}$ in $1 \mathrm{~m}$ wide bed. Manures and fertilizers were applied as per recommended dose. Seeds were sown on November, 2011 in separate plots. The seedling emerged 9-12 days after sowing. Thirty five days old seedlings were transplanted in the experimental plot. Weeding was done as and when necessary to keep the crop free from weeds. Irrigation was given to the plants when necessary. Data on plant height $(\mathrm{cm})$, number of secondary branch/plant, canopy breadth (cm), days to first flowering, days to $50 \%$ flowering, fruits/plant, 5 fruits weight (g), fruit length $(\mathrm{cm})$, fruit diameter $(\mathrm{cm})$, seeds/fruit, 1000 seed weight (g) and yield/plant (g) were recorded on individual plant basis from the 10 plants selected at random per plot. Mean data of each character was subjected to multivariate analysis viz. Principal Coordinate Analysis (PCO) Principal Component Analysis (PCA), Cluster Analysis and Canonical Variate Analysis using GENSTAT5 (Digby et al., 1989; Jager et al., 1983) program in computer.

\section{Results and Discussion}

The computations from distance matrix gave non-hierarchical clustering among 54 chili genotypes and grouped them into seven clusters (Table 1). Cluster II contained the highest number of chili genotypes (thirteen), followed by cluster I constituted by ten chili genotypes. Cluster III was composed of single genotype BSMRAU Sel-7 indicated that this genotype is totally different from other genotypes used in this study. Cluster IV, VI and VII constituted of nine genotypes each. Cluster V comprises of three chili genotypes.

Karad et al. (2002) reported eight clusters with 40 genotypes. Manju and Sreelathakumary (2004) reported six clusters with 32 accessions. Senapati et al. (2003) reported six clusters in 20 diverse genotypes of chili and Amarul J unior et al. (2005) reported eight distinct grouped in 50 accessions of chili.

Table1. Distribution of 54 Chili genotypes in different clusters grown in Rabi season of 2011-12

\begin{tabular}{|c|c|c|c|}
\hline Cluster no. & No. of Genotypes & $\begin{array}{l}\text { Number of } \\
\text { population }\end{array}$ & Chili genotypes \\
\hline I & $\begin{array}{l}3,10,21,33,39,41,42, \\
50,51,54\end{array}$ & 10 & $\begin{array}{llll}\text { Premium LT, BSMRAU Sel-1, Bindu, BSMRAU } & \text { BSMUU Sel-26, BSMRAU Sel-28, } \\
\text { Sel-20, BSMRAU Sel } & \text { BSMRAU Sel-29, Fire Cracker, PP-7, PP-10 }\end{array}$ \\
\hline II & $\begin{array}{l}5,6,7,8,15,17,20,25 \\
35,43,47,48,52\end{array}$ & 13 & $\begin{array}{l}\text { BSMRAU Sel-6, BSMRAU Sel-8, Sonic Super, } \\
\text { BSMRAU Sel-13, BSMRAU Sel-22, BSMRAU Sel- } \\
\text { 30, Fire Volcano, , HPCT-1946, PP-8 }\end{array}$ \\
\hline III & 16 & 1 & BSMRAU Sel-7 \\
\hline IV & $\begin{array}{l}19,22,26,29,31,32,37 \\
40,46\end{array}$ & 9 & $\begin{array}{l}\text { OP-collection, BSMRAU Sel-10, BSMRAU Sel-14, } \\
\text { Bindu-2, BSMRAU Sel-18, BSMRAU Sel-19, } \\
\text { BSMRAU Sel-24, BSMRAU Sel-27, Bindu-3 }\end{array}$ \\
\hline $\mathrm{V}$ & $2,27,45$ & 3 & HPCT-1947, BSMRAU Sel-15, BSMRAU Sel-32 \\
\hline VI & $\begin{array}{l}1,4,9,23,34,38,44,49 \\
53\end{array}$ & 9 & $\begin{array}{l}\text { PP 4651, Premium long, HP86235, BSMRAU Sel- } \\
\text { 11, BSMRAU Sel-21, BSMRAU Sel-25, BSMRAU } \\
\text { Sel-31, RK-221, PP-9 }\end{array}$ \\
\hline VII & $\begin{array}{l}11,12,13,14,18,24,28 \\
30,36\end{array}$ & 9 & $\begin{array}{l}\text { BSMRAU Sel-2, BSMRAU Sel-3, BSMRAU Sel-4, } \\
\text { BSMRAU Sel-5, BSMRAU Sel-9, BSMRAU Sel-12, } \\
\text { BSMRAU Sel-16, BSMRAU Sel-17, BSMRAU Sel-23 }\end{array}$ \\
\hline
\end{tabular}

Intra (bold) and inter cluster distances shown in Table 2. The inter-cluster distances were larger than the intra cluster distances. The inter-cluster distance was maximum between clusters I and III
(28.820) indicating wide genetic diversity between these two clusters followed by the distance between cluster III and VI (24.738), cluster II and cluster III (21.415) and cluster III 
and cluster VII (18.351). Genotypes from these four clusters if involve in hybridization may occur a wide spectrum of segregating population as genetic diversity is very distinct among the groups. The selection of diverge genotype from cluster would produce a broad spectrum of variability for morphological and quality traits studied which may enable further selection and improvement.

Table 2. Intra (bold) and inter cluster distances ( $\mathrm{D}^{2}$ ) for 54 chili genotypes

\begin{tabular}{clllllll}
\hline Clusters & I & II & III & IV & V & VI & VII \\
\hline I & $\mathbf{1 0 5 6}$ & 7.917 & 28.820 & 16.541 & 13.828 & 4.492 & 10.975 \\
II & & $\mathbf{0 . 8 3 7}$ & 21.415 & 8.875 & 7.282 & 3.830 & 3.760 \\
III & & & $\mathbf{0 . 0 0 0}$ & 13.257 & 17.936 & 24.738 & 18.351 \\
IV & & & & $\mathbf{0 . 4 8 5}$ & 6.287 & 12.364 & 6.011 \\
V & & & & & $\mathbf{0 . 8 2 7}$ & 9.758 & 5.800 \\
VI & & & & & & $\mathbf{0 . 9 2 9}$ & 6.779 \\
VII & & & & & & & $\mathbf{0 . 6 2 2}$ \\
\hline
\end{tabular}

The minimum inter-cluster distance was observed between cluster II and cluster VII (3.760) followed by cluster II and cluster VI (3.830) and cluster I and cluster VI (4.492) indicating that the genotypes of these clusters were genetically close. Cluster mean value of 12 different characters shown in Table 3. Difference in cluster means existed for almost all the characters studied. Highest mean value for plant height $(\mathrm{cm})$, number of secondary branch/plant, canopy breadth (cm), fruits/ plant, 5 fruits weight $(\mathrm{g})$, fruit length (cm), seeds/fruit and yield/plant (g)was observed in cluster III that means the genotype fallen in cluster III having the genetic potentiality to contribute better for yield maximization of chili genotypes. Cluster V possessed genotypes with maximum number of fruits coupled with dwarf plant stature and earliness indicating selection of genotypes from these cluster for future chili breeding program have positive impact for short plant type, earliness and number of fruits. Cluster I had the genotypes that showed lowest mean value for almost all the characters studied indicating selection of genotypes from these cluster for future chili breeding program have no positive impact except for dwarfness.

Table 3. Cluster mean values of 12 different characters of 54 Chili genotypes

\begin{tabular}{llllllll}
\hline Characters & I & II & III & IV & V & VI & VII \\
\hline Plant height $(\mathrm{cm})$ & 77.8 & 87 & 100 & 87.8 & 85 & 85.8 & 85.1 \\
Secondary branches/plant & 7 & 9.8 & 12 & 9.6 & 8.7 & 8.1 & 7 \\
Canopy breadth $(\mathrm{cm})$ & 51.2 & 65.3 & 100 & 63.1 & 80 & 62.8 & 65.7 \\
Days to first flowering & 83.1 & 85.3 & 75 & 81.6 & 74.7 & 86.1 & 80.7 \\
Days to 50\% flowering & 90.2 & 93.3 & 83 & 89.9 & 82.7 & 93.7 & 88.4 \\
Fruits/ plant & 105.7 & 217.1 & 404 & 382 & 538 & 196.4 & 264.4 \\
5 fruits weight $(\mathrm{g})$ & 16.4 & 20.8 & 25 & 19.8 & 10.7 & 16.6 & 20 \\
Fruit length $(\mathrm{cm})$ & 5.6 & 6.6 & 7.6 & 6.4 & 6.4 & 7.1 & 7.1 \\
Fruit diameter $(\mathrm{cm})$ & 1.1 & 1.4 & 1.3 & 1.3 & 0.8 & 1.1 & 1.3 \\
Seeds/fruit & 49.8 & 53.8 & 82 & 55.2 & 49.3 & 50.9 & 53.4 \\
1000 seed weight (g) & 3.8 & 3.8 & 3.7 & 3.8 & 3.8 & 3.8 & 3.8 \\
Yield/ plant (g) & 334.1 & 829 & 2210 & 1413.6 & 1125.7 & 595.6 & 1023.6 \\
\hline
\end{tabular}

Relative contribution towards divergence presented in Table 4. Vector-1 and Vector-2 values were obtained from principal component analysis. In first axis Vector-1, all the studied characters had positive impact towards divergence except fruits/plant. In Vcetor-1 the important characters responsible for divergence in the major axis of differentiation were 5 fruits weight (0.4587), plant height (0.3737), fruit diameter (0.3476) and seeds/fruit (0.3437). In vector-2, fruits/plant (0.4653), yield/plant
(0.4255) canopy breadth (0.3122), secondary branches/plant (0.2277) and plant height (0.1315) had better positive impact towards divergence. The character that showed positive value in both Vectors contributed most towards divergence. That means yield/plant, canopy breadth, secondary branches/plant, plant height and seeds/fruit contributed most for divergence in the studied genotypes. Present findings are accordance with the findings of Mubarak Begum (2002) and Prabhudeva (2003). 
Table 4. Relative contributions of the twelve characters of 54 Chili genotypes to the total divergence

\begin{tabular}{lcc}
\hline Characters & Vector-1 & Vector-2 \\
\hline Plant height (cm) & 0.3737 & 0.1315 \\
Secondary branches/plant & 0.3007 & 0.2277 \\
Canopy breadth (cm) & 0.2645 & 0.3122 \\
Days to first flowering & 0.2233 & -0.4275 \\
Days to 50\% flowering & 0.2341 & -0.4085 \\
Fruits/ plant & -0.0632 & 0.4653 \\
5 fruits weight (g) & 0.4587 & -0.1369 \\
Fruit length (cm) & 0.2472 & 0.0545 \\
Fruit diameter (cm) & 0.3476 & -0.0788 \\
Seeds/ fruit & 0.3437 & 0.0858 \\
1000 seed weight (g) & 0.1528 & -0.2258 \\
Yield/plant (g) & 0.2398 & 0.4255 \\
\hline
\end{tabular}

Genotypically distant parents are able to give high heterosis. Therefore, considering group distance, mean performance and variability the inter genotypic crosses between cluster I and cluster III, cluster III and cluster VI, cluster II and cluster III and cluster III and cluster VII may be suggested to use for future hybridization program. Superior genotype BSMRAU Sel-7 fallen in cluster III had shown best results on canopy breadth, secondary branches/plant, fruit weight, fruit length, seeds/fruit and yield/plant. Hence, these characters should be given prime importance for further improvement in yield in further breeding program

\section{References}

Amarul Junior, A.T., Rodrigues, R., Sudre, C.P., Riva, E.M. and Karasawa, M. 2005. Genetic divergence between 'chilli' and sweet pepper accessions using multivariate techniques. Horticultura Brasileira 23 (1): 22-27.

BBS. 2011. Year book of Agricultural Statistics of Bangladesh. Planning Division, Ministry of Planning, Govt. of the People's Republic of Bangladesh, Dhaka. pp. 23-27.

Digby, P.N., Galway and Lane, P. 1989. Genstat 5: A second course. Oxford Sci. Publication, Oxford. pp. 103-108.

Dutonde, S.N., Bhalekar, M.N., Patil, B.T., Kshirsagar, D.B. and. Dhumal, S.S. 2008. Genetic diversity in chili (Capsicum annuum L.). Agric. Sci. Digest 28 (1): 45-47.

Farhad, M.I., Hasanuzzaman, M., Biswas, B.K. Arifuzzaman, M. and Islam, M.M. 2010. Genetic divergence in chilli (Capsicum annuum L.). Bangladesh Res. Publ. J. 3 (3): 1045-1051.

Gaur, P.C., Gupta, P.K. and Kishore, H. 1978. Studies on genetic divergence in potato. Euphytica 27: 361-368.

Jager, M.I.D., Garethojones, I.D. and Griffith, E. 1983. Component of partial resistance of wheat seedlings to Septoria nodorum. Euphytica 32: 575-584.
Karad, S.R., Raikar, G.R. and Navale, P.A. 2002. Genetic divergence in chilli. J. Maharashtra Agril. Univ. 27 (2): 143-145.

Manju, P.R. and Sreelathakumary, I. 2004. Genetic divergence in hot chilli (Capsicum chinense Jacq.). Capsicum and Eggplant Newsl. pp. 69-72.

Mubarak Begum, S. 2002. Evaluation of chilli germplasm for productivity, its component traits and resistance to some biotic stresses. M.Sc. (Agri.) Thesis, University of Agricultural Sciences, Dharwad. p. 29.

Patel, M.Z, Reddi, M.V., Rana, B.S. and Reddy, B.J. 1989. Genetic divergence in safflower (Carthamus tinctorius L.). Indian J. Genet. 49 (1): 113-118.

Prabhudeva, S.A. 2003. Variability genetic diversity and heterosis study in chilli (Capsicum annuum L.). M.Sc. Thesis, University of Agricultural Sciences, Dharwad. pp. 31-32.

Ramanujam, S., Tiwary, A.S. and Mehra, R.B. 1974. Genetic divergence and hybrid performance in mungbean. Theor. Appl. Genet. 44 (5): 211-214.

Senapati, B.K., Sahu, F.K. and Sarkar, G. 2003. Genetic divergence in chilli. Crop Res. Hisar. 26 (2): 314-317.

Tomooka, N. 1991. Genetic diversity and landrace differentiation of mungbean, (Vigna radiata L.) Wilczek, and evaluation of its wild relatives (The subgenus Ceratotropics) as breeding materials. Tech. Bull. Trop. Res. Centre, Japan No. 28. Ministry of Agriculture, Forestry and Fisheries. Japan. p. 1. 